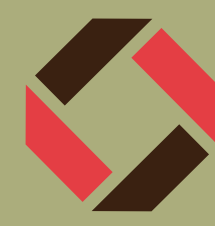

\section{Intel's Carolyn Duran ensures conflict-free minerals supply chain}

\section{By Prachi Patel}

$\mathrm{M}$ aterials scientists do not typically get a chance to impact thousands of lives in a war-ravaged African country. So when Carolyn Duran stumbled upon just such an opportunity six years ago, she knew she had to act. Duran was a supply chain manager at Intel Corporation's Hillsboro, Oreg., campus when she heard about the company's new conflict-free minerals team.

What she learned was disturbing. Intel's semiconductor chips may have used metals extracted from minerals mined in regions of the Democratic Republic of Congo (DRC) that have been embroiled in civil war for two decades. Armed rebel militias control and profit from these mines, forcing

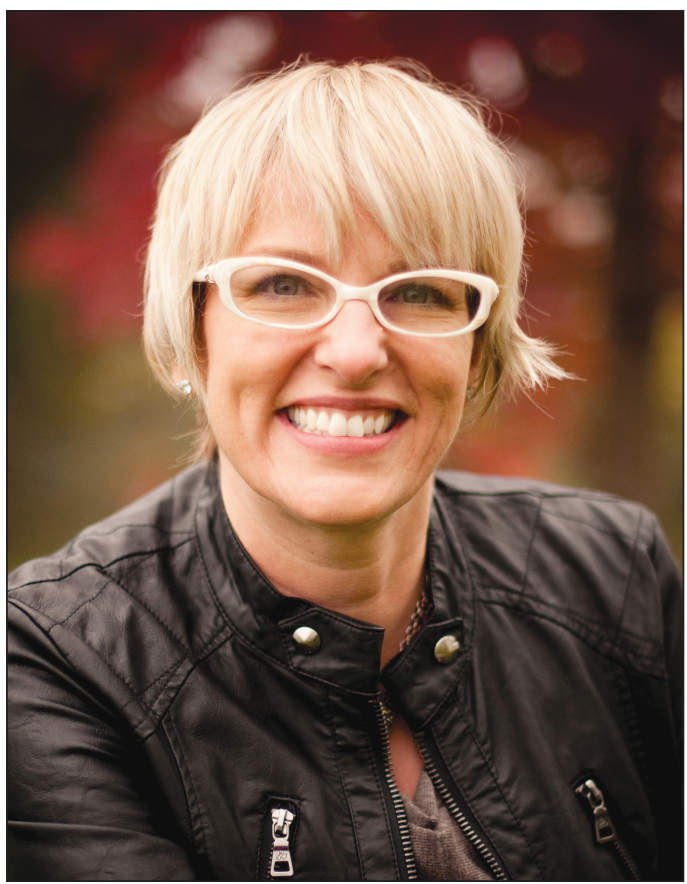

Carolyn Duran, Director of Supply Chain Sustainability at Intel. people to work in atrocious conditions, using murder and rape as tools, and employing child soldiers. Over 5 million people have died there since 1998.

Intel's CEO Brian Krzanich, then the company's COO, started the conflict-free mineral program in response to an appeal from the nonprofit Enough Project, which fights crimes against humanity in Africa. Krzanich wanted to eliminate conflict minerals that fuel armed violence from Intel's supply chain.

Duran took over the team, not knowing what she was getting into. Working methodically and painstakingly, she made Krzanich's goal a reality. Not by retracting from the Congo, but by sourcing minerals from audited mines that do not fund armed groups.

In 2014, Intel declared its microprocessors conflictfree. In early 2016, the company announced that every single product it ships will be conflict-free.

"There have been egregious human rights atrocities taking place over a decade in the DRC," says Duran, who is now Director of Supply Chain Sustainability at Intel. "People are decimated, it's the rape capital of the world. Our goal is to make sure that the metals we use are sourced responsibly."

The metals at the core of the issue are gold and the 3T elements tantalum, tin, and tungsten, all of which are crucial to the electronics that go into computers and cell phones. About 8-20\% of tantalum, 4\% of tin and tungsten, and $1 \%$ of gold come from the Congo, Duran says.

A relatively simple route would have been to avoid the Congo completely. Some companies have chosen that option. But that would hurt an already desperate population, Duran says. "In these countries, mining and agriculture are the primary means of livelihood," she says. "If you completely stop doing business in the region you could hurt legitimate mining in the region. Is embargoing the region the right thing to do for people on the ground?"

Intel chose the alternative: do business with legitimate mines. Track down where the metals enter Intel's supply chain, and ensure that they come from conflict-free mines. It was a huge, daunting task. Supply chains are usually long, complicated, and non-transparent. And it is very difficult to verify that minerals coming from a region are conflictfree. With no system in place, the team was starting from scratch. "A lot of our early work was just figuring out what we could do," she says. "We had to figure out a process, how to do it, convince others to join us and keep it viable. There were challenges in every step."

The first step was unraveling the supply chain. Intel has no direct link to the mines. The company buys purified metals from suppliers that have ties to smelters all over the world. These smelters purchase raw ore from other companies in Africa, which in turn buy the minerals from traders who deal with hundreds of small mines in the Congo region.

After some sleuthing, Duran realized that the smelters that refine raw ore into metals were the pinch point in the supply chain. Although there are thousands of mines around the world, there are only a few hundred smelters that process metals for semiconductor chips.

Intel joined forces with non-governmental organizations, governmental bodies, a few other industry leaders including Hewlett Packard, Apple, and Motorola, and with the Electronic Industry Citizenship Coalition, and started with tantalum. The team helped establish a third party auditing system called the Conflict-Free Smelter 


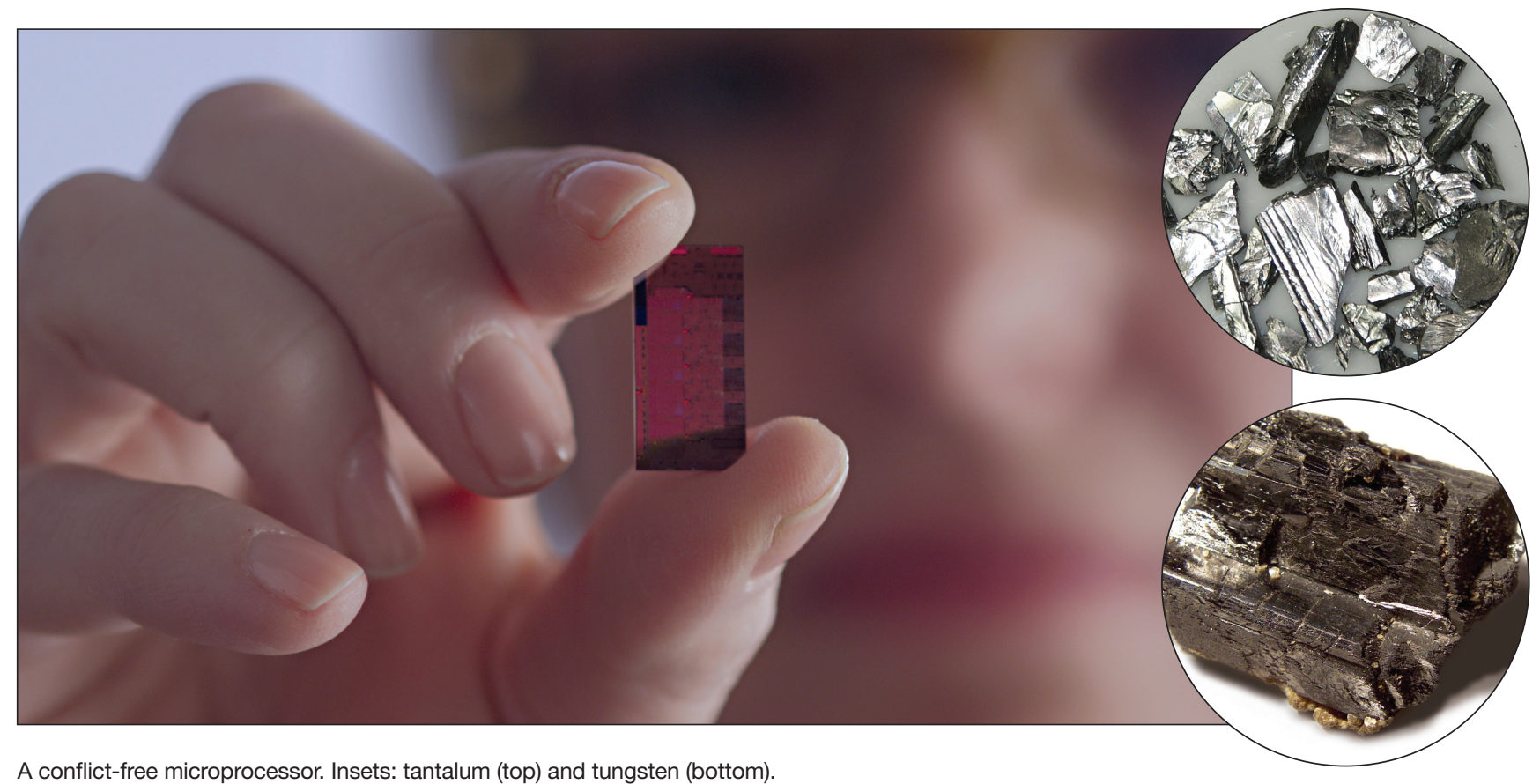

A conflict-free microprocessor. Insets: tantalum (top) and tungsten (bottom).

Program. Independently in June 2011, the United Nations, the Organization for Economic Cooperation and Development, and the DRC government put together a mine rating system.

Over five years, Duran and her team visited 85 smelters in 21 countries, making smelter owners aware of the problem and trying to convince them to join Intel's efforts and go through the audit process.

"The biggest challenge was that most smelters and refiners aren't in the US," Duran says. There were language and cultural barriers. "Just as an example, we had trouble engaging Chinese smelters and suppliers in the efforts," she says. "They'd say "what do I have to do with the Congo? It's not my problem."'

But Duran persisted. She and her team coaxed smelter owners to join Intel's cause if they wanted to continue selling to the company. When smelters said they couldn't afford the audit, Krzanich authorized funds to cover the costs. The first smelter was audited in 2010. Others saw the benefits of being audited and certified conflict-free. Pressure from multiple companies and organizations helped, as did regulations such as the 2010 U.S. Dodd-Frank Law that required companies to disclose their use of minerals from Africa.
"From the smelters' perspective, at the end of the day it's a purchasing business proposition," she says. "We told them we're only going to buy from you if you show responsible sourcing. Many did."

But the company also ended up losing some smelters. That caused some fluctuation in supply, but it quickly stabilized and did not affect metal costs in the long run.

Central to the Conflict-Free Smelter Program is a "bag and tag" method to track minerals from positively rated mines. As soon as the minerals are pulled out of the typically artisan mines in the Congo, Duran says, they are put in a bag with an origin tag. The bag is then monitored from mine to the export country and ultimately at the smelter. The process might not be foolproof given rampant corruption and bribery, but it minimizes the chance of conflict metals entering the supply chain.

An ongoing challenge is that the situation on the ground is forever changing. This changes the availability and cost of the metals. "Suppliers can be OK one year and then fail their audit the next year," she says. "A mine that's green today won't be tomorrow. So there's some instability there. Trying to have everyone working together on this goal is hard."
Thanks in big part to Duran's dogged efforts, today more than half the world's $3 \mathrm{~T}$ and gold smelters have passed conflict-free audits, and $90 \%$ of the world's tantalum supply is conflict-free. When Intel declared their microprocessors conflict-free, it triggered dozens of other businesses, including aircraft, lighting, and jewelry manufacturers who also use the metals, to join the race toward responsibly sourced minerals.

"Carolyn's efforts were pivotal to making this happen," says Jackie Sturm, Vice President of Global Supply Management at Intel, who is Duran's manager. "She understands that all involved parties have pressures and boundaries, works well with others to create mutually acceptable actions, and then she is single-minded in holding everyone accountable to their commitments, but in a very constructive way."

Duran joined Intel's research and development laboratory in 1998 right after she earned her $\mathrm{PhD}$ degree in materials science from Northwestern University. At the time she never thought she would be participating in something so meaningful.

"It was a lucky accident," she says. "When you learn about an issue like this, you just have to do something." 
Sigma-Aldrich

Lab Materials \& Supplies
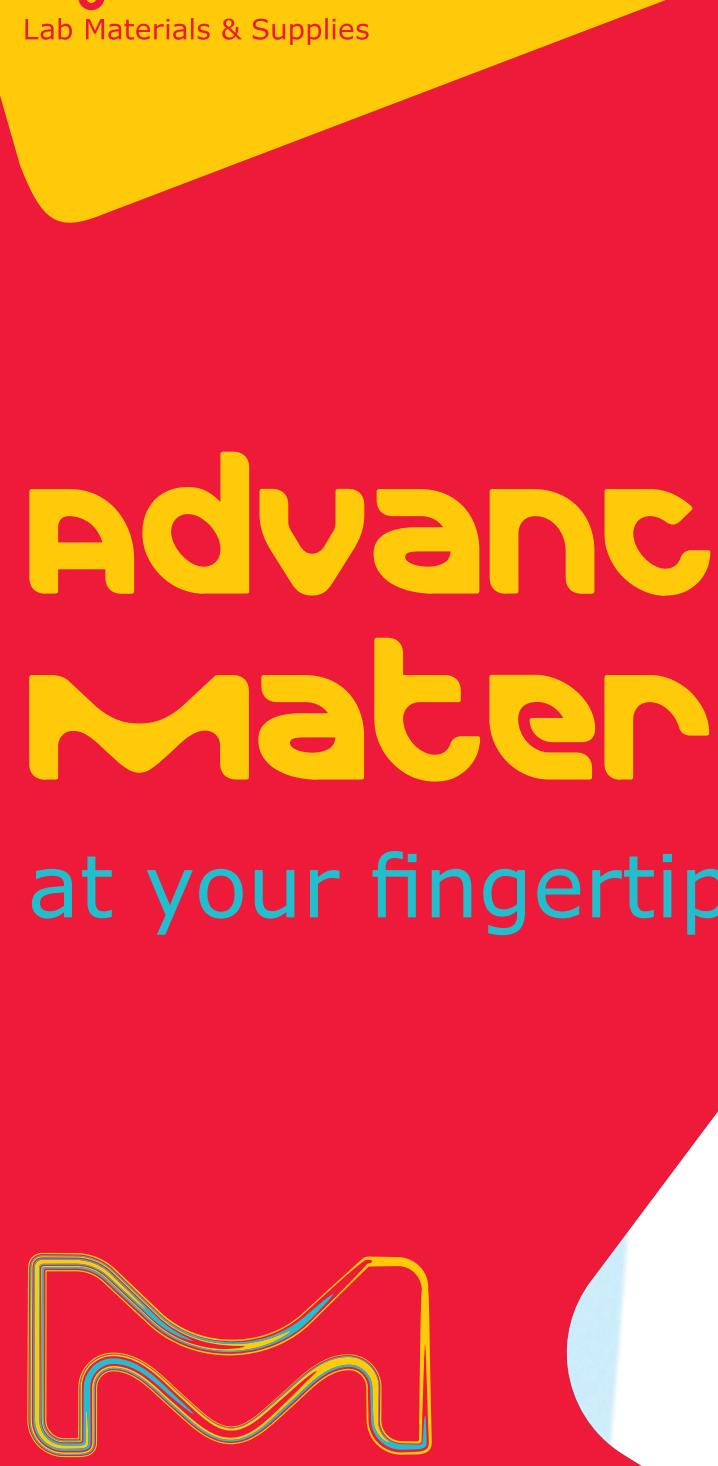

Then. Now. Always.

Your trusted partner in Materials Science.

sigma-aldrich.com/matsci

\section{Biomedical | Energy | Electronics}




\section{OPEN}

ACCESS.

\section{RAPID \\ PUBLICATION.}

GLOBAL

REACH.

Submit your research at pubs.acs.org/acsomega

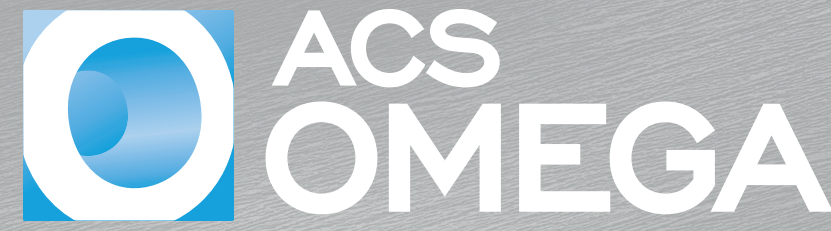

THE NEWEST OPEN ACCESS CHEMISTRY JOURNAL FROM ACS PUBLICATIONS

\section{Give your research some air.}

Submit your high impact chemistry discovery to ACS Central Science.

Blaze a trail to fast, free open access publication.

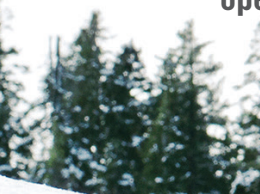

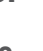

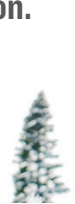

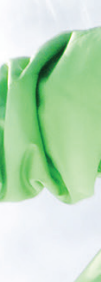



pubs.acs.org/acscentralscience

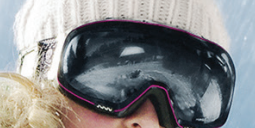

Lin

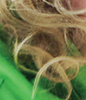

$\infty$ 
FOLLOW US ON TWITTER

@acsenergylett
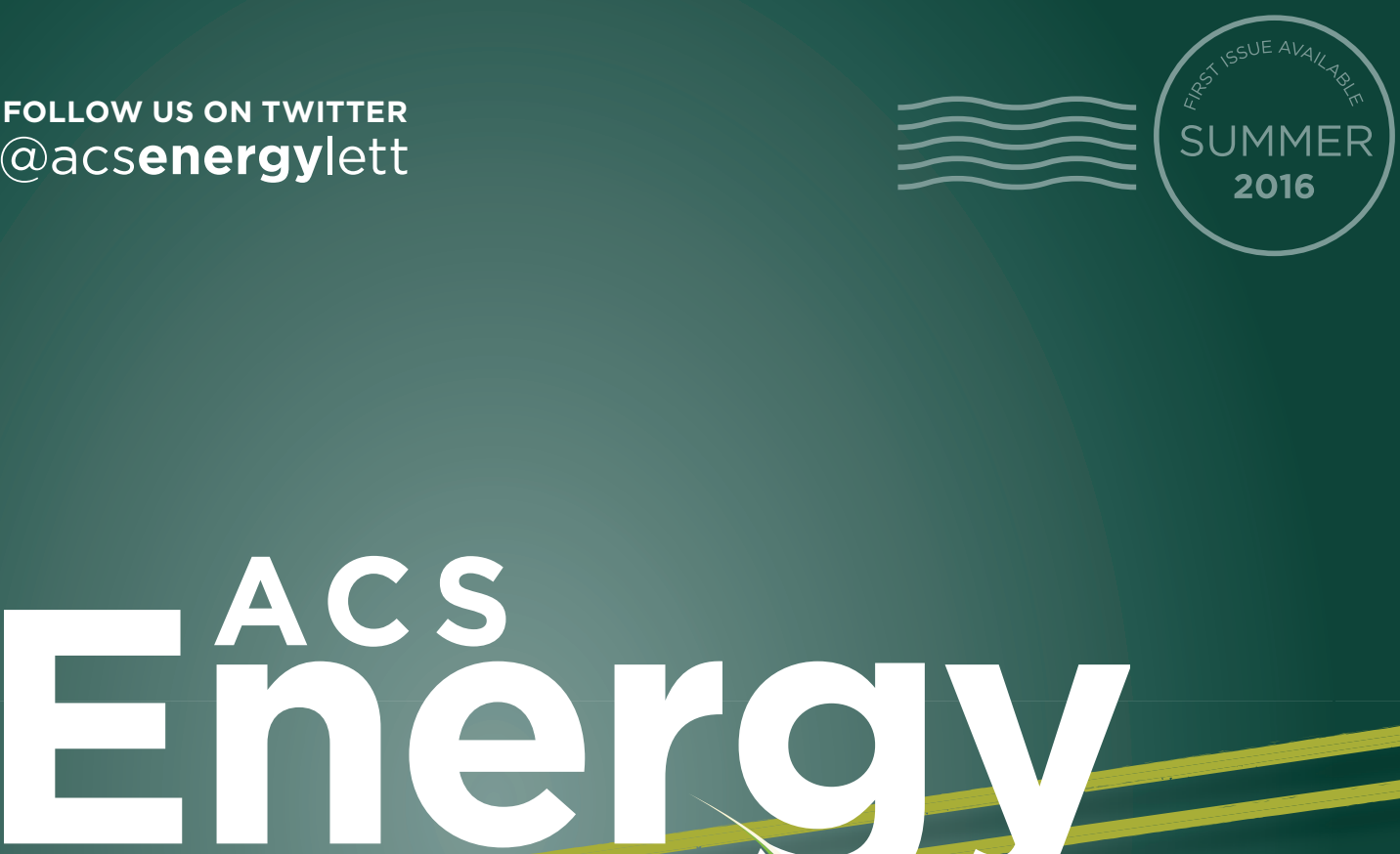

LETTERS
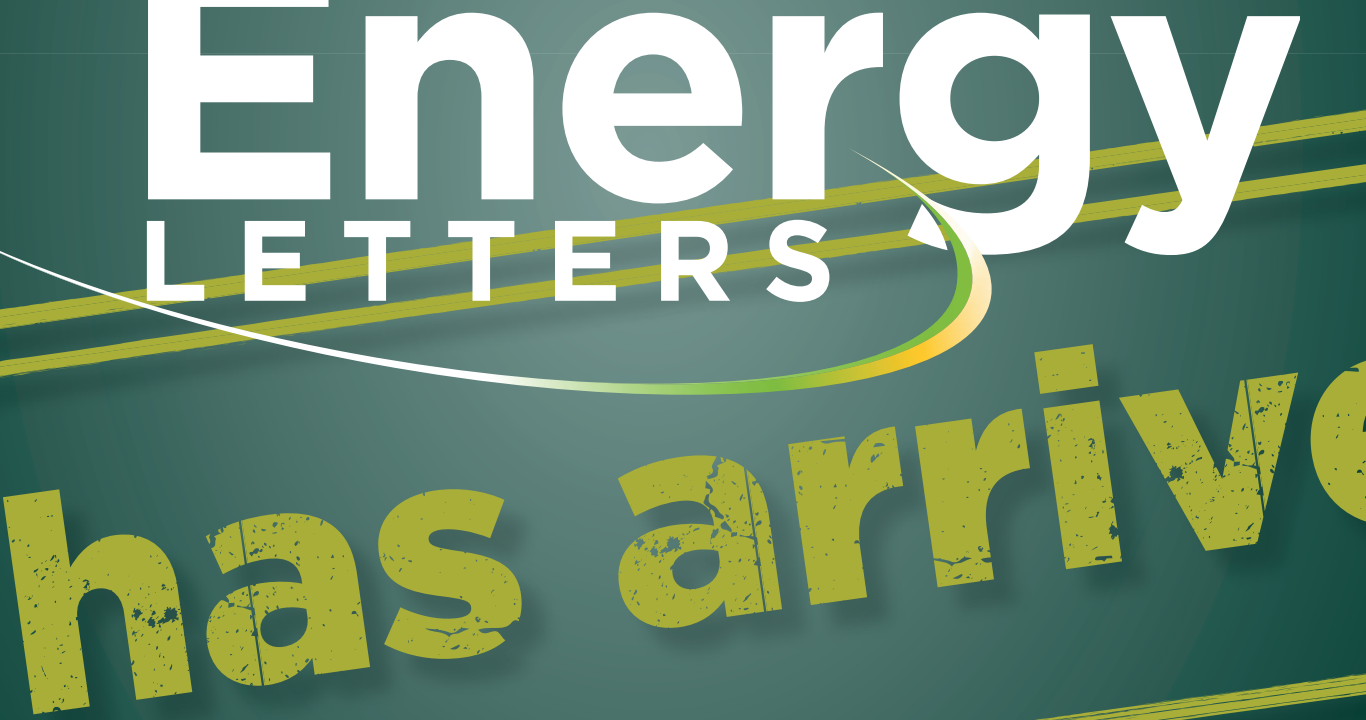

Get complimentary access at
pubs.acs.org/acsenergyletters 